\title{
African American Women Honored with Congressional Gold Medals
}

\section{Karen Saxe}

On November 8, 2019, the president signed into law the Hidden Figures Congressional Gold Medal Act. ${ }^{1}$ Congressional Gold Medals will go to Katherine Johnson and Dr. Christine Darden, and posthumously to Dorothy Vaughan and Mary Jackson. The law also awards "a Congressional Gold Medal to honor all of the women who contributed to the success of the National Aeronautics and Space Administration during the Space Race." More precisely, the law requires the presentation of

- one Congressional Gold Medal to Katherine Johnson, in recognition of her service to the United States as a mathematician;

- one Congressional Gold Medal to Dr. Christine Darden, for her service to the United States as an aeronautical engineer;

- two Congressional Gold Medals in commemoration of the lives of Dorothy Vaughan and Mary Jackson, in recognition of their service to the United States during the Space Race; and

- one Congressional Gold Medal in recognition of all the women who served as computers, mathematicians, and engineers at the National Advisory Committee for Aeronautics and the National Aeronautics and Space Administration (NASA) between the 1930 s and the 1970 s.

Karen Saxe is associate executive director of the AMS and director of the Office of Government Relations. Her email address is kxs@ams.org.

1 https://www. congress.gov/bi11/116th-congress/house-bi11 $/ 1396$

For permission to reprint this article, please contact: reprint-permission aams.org.

DOI: https://dx.doi.org/10.1090/noti2051
They "were integral to the success of the early space program," serving as the first "computer pool" at the Langley Memorial Aeronautical Laboratory. ${ }^{2}$ Their mathematical achievements include calculating the trajectory for Alan Shepard's 1961 Freedom 7 mission, improving designs to minimize the effects of sonic booms, and researching the boundary layer of air around aircraft.

These women, the subject of the movie Hidden Figures, adapted from Margot Lee Shetterly's book of the same name, were engineers and mathematicians who broke down barriers and paved the way for women of color in STEM. Shetterly has participated twice at the Joint Mathematics Meetings, once in $2017^{3}$ and again in $2019^{4}$ when she was awarded the Joint Policy Board for Mathematics Communications Award. ${ }^{5}$ Dr. Darden also attended JMM 2017.

The Congressional Gold Medal is the highest civilian award in the United States. George Washington received the first Congressional Gold Medal in 1776. Since then there have been roughly 150 given-some to individuals, some to groups (e.g., in 2016 there was one given to "Filipino Veterans of World War II"). To give a sense of scale_in 2017 one was awarded, and in 2018 there were four (but only two to individuals). Scientists are among awardees, and include:

- Wilbur and Orville Wright (1909), who were the first aeronautical or space pioneers to receive a gold medal, for their achievements in demonstrating to the world the potential of aerial navigation.

\footnotetext{
2https://www. congress.gov/116/crec/2019/09/19/modi fied/CREC -2019-09-19-pt1-PgH7812.htm

3 https://blogs.ams.org/jmm2017/2017/01/05/the-mathematics -and-mathematicians-of-hidden-figures/

${ }^{4}$ https://www.ams.org/journals/notices/201906/rnoti-p923.pdf

${ }^{5}$ https://www.ams.org/journals/notices/201904/rnoti-p620.pdf
} 
- Lincoln Ellsworth (1928), the first explorer honored, for his polar flight in 1925 and transpolar flight in 1926.

- Major Walter Reed and his associates (1929), who were the first scientists honored, for discovering the cause and means of transmission of yellow fever in 1921.

Overall, there are not many scientists recognized with this award, and Katherine Johnson is the first to receive it in recognition of service as a mathematician.

It is hard to pass laws. Indeed, only sixty-eight laws have been passed in the 116th Congress thus far (as of this writing, November 13, 2019). ${ }^{6}$ Special rules apply for passing this particular type of legislation-all Congressional Gold Medal legislation must be cosponsored by at least twothirds (290) of the members of the House and by at least sixty-seven senators. Senator Chris Coons from Delaware and Congresswoman Eddie Bernice Johnson from Texas introduced the Hidden Figures Act in Congress. After the introduction, the next step was to get the requisite number of cosponsors.

The AMS Office of Government Relations (AMS OGR) talked to many members of Congress, urging them to support the bill that would finally recognize these trailblazers. Mathematicians responded to the Call to Action (posted on the AMS OGR website) and wrote their congressional delegations-informing them about the importance of the work of these women as computers, mathematicians, and engineers at the National Advisory Committee for Aeronautics and the National Aeronautics and Space Administration between the 1930s and the 1970s-requesting that they cosponsor the bill. A sufficient number of cosponsors stepped up, and the bill was brought to the floor in each chamber for final votes. It passed the House by voice vote, and passed in the Senate without amendment and by unanimous consent. ${ }^{7}$

The first female to be recognized with a Congressional Gold Medal was Anna Bouligny (1938). Since then, only about a dozen other women have been individually recognized. This new batch of awardees, therefore, adds significantly to the list of female Congressional Gold Medal recipients and is worth celebrating especially during Women's History Month.

6ttps://bit.7y/33VUggE

https://www. congress.gov/bi11/116th-congress/house-bi11 71396

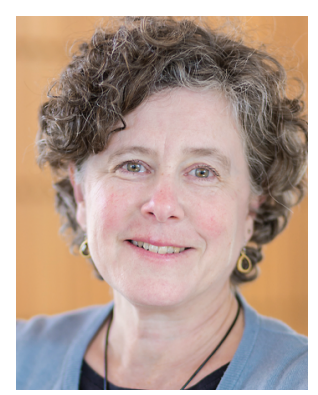

Karen Saxe

Credits

Author photo is courtesy of Macalester College/David Turner.

\section{AMS Bookstore?}

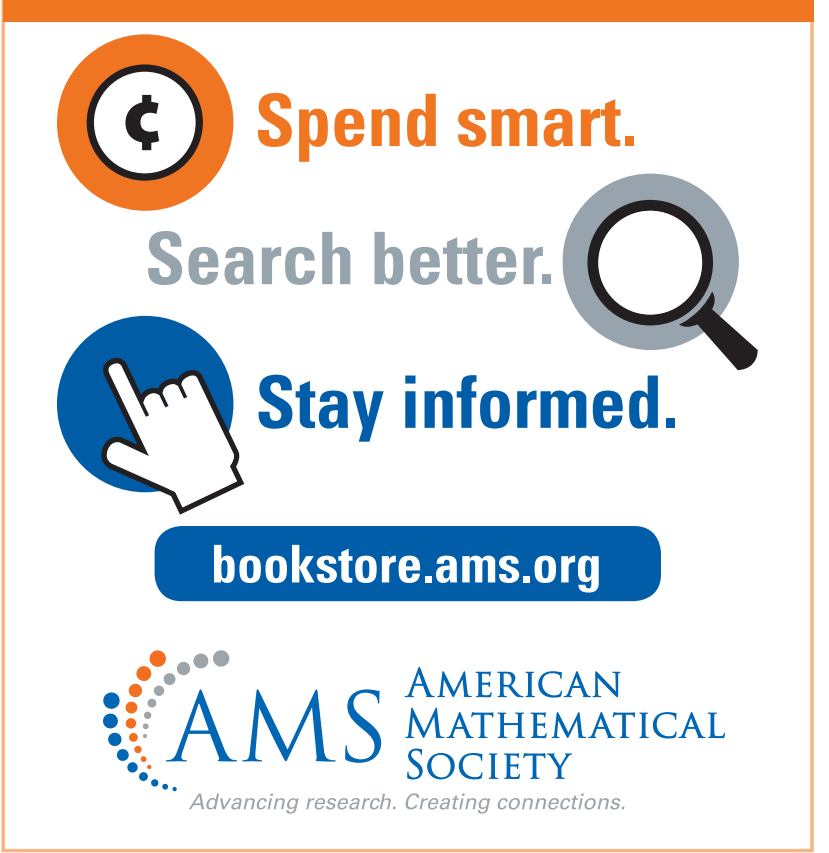

